\title{
Isolated Aplasia Cutis Congenita on Left Foot in Chinese Neonate
}

\author{
Siddiq Muhammad1, A. Sultana², Mi Xiao', Naz Iram¹, Xian-Hua Piao³, Huihui Duan", Li Liu1* \\ ${ }^{1}$ Department of Neonatology, The First Affiliated Hospital, Xi'an Jiaotong University College of Medicine, Xi'an, China \\ ${ }^{2}$ Institute of Child Health and SSF Hospital Mirpur 2, Affiliated Hospital by Bangladesh College of Physician and Surgeon and \\ Bangabandhu Sheikh Mujib Medical University, Dhaka, Bangladesh \\ ${ }^{3}$ The Division of Newborn Medicine, Department of Medicine, Boston Children's Hospital and Harvard Medical School, \\ Boston, USA \\ ${ }^{4}$ Department of Aesthetic Plastic and Craniofacial Surgery, The First Affiliated Hospital, Xi'an Jiaotong University College of \\ Medicine, Xi'an, China \\ Email:*liuli918@163.com
}

How to cite this paper: Muhammad, S. Sultana, A., Xiao, M., Iram, N., Piao, X.-H., Duan, H.H. and Liu, L. (2017) Isolated Aplasia Cutis Congenita on Left Foot in Chinese Neonate. Open Journal of Pediatrics, 7, 44-50.

https://doi.org/10.4236/ojped.2017.71007

Received: January 7, 2017

Accepted: March 27, 2017

Published: March 30, 2017

Copyright (c) 2017 by authors and Scientific Research Publishing Inc. This work is licensed under the Creative Commons Attribution International License (CC BY 4.0).

http://creativecommons.org/licenses/by/4.0/

\begin{abstract}
Aplasia Cutis Congenita (ACC) is a rare condition characterized by absence of skin layers, usually on the scalp, but can also affect the foot. ACC can occur as an isolated condition or in the presence of the other congenital anomalies. Here we describe a case of a 1-day-old baby boy with an isolated ACC of the left foot, with no family or siblings positive disease history. The patient was managed by both conservatively and surgically until the defect has formed scar tissue 5 months later.
\end{abstract}

\section{Keywords}

Isolated Congenital Cutis Aplasia, Congenital Abnormality, Dermatology, Pediatrics

\section{Introduction}

Aplasia Cutis Congenita (ACC) is a rare congenital abnormality involving variant layers of the skin, mostly as a solitary lesion involving the midline over the skull vertex [1]. May occur in other sites as well as the chest, abdomen, or limbs, less commonly, underlying periosteum and bone [2] [3]. It was first described in 1767 by Cordon, around 500 similar cases have been reported so far [4]. Frieden classified the different anomalies into 9 groups based on the number and the presence or absence of other anomalies [5] (Table 1). The lesions in those cases are quite variable, ranging from only local absence of skin to a complete absence of epidermis, subcutaneous tissue, bone, or in some cases the dura [6] [7]. The 
Table 1. Classification for ACC.

\begin{tabular}{|c|c|c|c|}
\hline & Group & Associated anomalies & Inheritance \\
\hline 1 & $\begin{array}{l}\text { Scalp ACC without multiple } \\
\text { anomalies }\end{array}$ & $\begin{array}{c}\text { Cleft lip and palate, tracheoesophageal fistula, patent ductus arteriosus, omphalocele, } \\
\text { mental retardation, polycystic kidneys }\end{array}$ & $\begin{array}{l}\text { Autosomal dominant } \\
\text { or sporadic }\end{array}$ \\
\hline 2 & $\begin{array}{l}\text { Scalp ACC with limb } \\
\text { abnormalities }\end{array}$ & $\begin{array}{l}\text { Limbs reduced, syndactyly, clubfoot, encephalocele, nail dystrophy or absence, persistent } \\
\text { cutis marmorata }\end{array}$ & Autosomal dominant \\
\hline & $\begin{array}{l}\text { Scalp ACC with skin/organoid } \\
\text { nevi }\end{array}$ & $\begin{array}{c}\text { Epidermal nevi, corneal opacities, sclera dermoids, eyelid colobomas, mental retardation, } \\
\text { seizures }\end{array}$ & Sporadic \\
\hline 4 & $\begin{array}{l}\text { ACC overlying embryologic } \\
\text { malformations }\end{array}$ & $\begin{array}{l}\text { Meningomyelocele, spinal dysraphia, cranial stenosis, leptomeningeal angiomatosis, } \\
\text { gastroschisis, congenital midline porencephaly, ectopia of ear, omphalocele }\end{array}$ & $\begin{array}{l}\text { Depends upon } \\
\text { underlying condition }\end{array}$ \\
\hline & $\begin{array}{l}\text { ACC with fetus papyraceus or } \\
\text { placental infarcts }\end{array}$ & $\begin{array}{l}\text { Single umbilical artery spastic developmental delay, spastic paralysis, clubbed hands and } \\
\text { feet, amniotic bands }\end{array}$ & Sporadic \\
\hline 6 & $\begin{array}{l}\text { ACC associated with } \\
\text { epidermolysis bullosa }\end{array}$ & $\begin{array}{l}\text { Blistering of skin and/or mucous membranes, deformed nails, pyloric or duodenal atresia, } \\
\text { abnormal ears and nose, ureteral stenosis, renal anomalies, amniotic bands }\end{array}$ & $\begin{array}{l}\text { Depends upon type of } \\
\text { epidermolysis bullosa }\end{array}$ \\
\hline & $\begin{array}{l}\text { ACC localized to extremities } \\
\text { without blistering }\end{array}$ & None & $\begin{array}{l}\text { Autosomal dominant } \\
\quad \text { or recessive }\end{array}$ \\
\hline 8 & ACC caused by teratogens & $\begin{array}{l}\text { Imperforate anus (methimazole), other signs of intrauterine infection with varicella or } \\
\text { herpes simplex }\end{array}$ & Not inherited \\
\hline 9 & $\begin{array}{l}\text { ACC associated with } \\
\text { congenital syndromes }\end{array}$ & $\begin{array}{l}\text { Trisomy } 13,4 \mathrm{p} \text {-syndrome, ectodermal dysplasia, focal dermal hypoplasia, amniotic band } \\
\text { disruption complex, XY gonadal dysgenesis, Johanson-Blizzard syndrome }\end{array}$ & $\begin{array}{l}\text { Depends upon } \\
\text { Syndrome }\end{array}$ \\
\hline
\end{tabular}

incidence of ACC is estimated as 1 per 10,000 live births [1]. This occurs frequently in females. The etiology remains unclear so far; however, both genetic and environmental causes have been implicated, including vascular blood supply, a sudden arrest of midline embryological development, and failure in neural tube closure, and syphilis has at one time contributed as the cause [1] [8]. Rupture of amniotic membrane in an early time, forming amniotic bands, may also be from the cause [5]. A number of teratogenic drugs such as Methimazole, a Thiomidazole derivative used as an antithyroid agent, have shown to be involved [9] [10]. There are similar cases, classified as being of an autosomal-dominant inheritance [11]. Establishing a diagnosis is usually based on the findings of the clinical examination, typically presenting as a hairless, smooth skin defect covered up by atrophic tissue or a dark colored eschar. Superficial defects presenting as an ulcer are usually treated conservatively. Extensive or deep defects may require reconstruction of the scalp area or the use of bone transplants.

\section{Case Summary}

A 4200 -g boy was delivered by a 27 -year-old mother, gravida 1 para 0 , by LUCS at 39 weeks of gestation due to oligohydramnios in changan district hospital Xi'an China, at the age of 1 day, the neonate was admitted to NICU of Xi'an Jiaotong first affiliated hospital because of the morphological abnormalities and abnormal skin over the left foot and leg since birth. The medical history of neonate was unremarkable, his mother denied any history of illness during her pregnancy except she had high blood pressure (140/95) before the 1 day of delivery, infection or drug intake including Methimazole or NSAIDS. The neonate didn't suffer any other feeding difficulties or abnormalities. Upon the local ex- 
amination the defect was solitary, localized with an approximately $5 \times 5 \mathrm{~cm}$ in size and irregular in shape. The patient was treated with conservative methods in the beginning like; local therapy and non-invasive debridement of the lesion, which included application of topical antibiotic ointment and gentle water cleansing. Although the conservative methods were showing gradually improvement but surgical treatment were also under consideration for further improvement due to its large lesion, as it can be prevented the fatal complications and the cosmetic results are usually better.

\subsection{On Examination}

T 35.6, P 124/min, R 45/min, BP 68/41 mmHg, WT $4200 \mathrm{~g}$, head circumference $35.0 \mathrm{~cm}$, length $52.0 \mathrm{~cm}$, chest circumference, $33 \mathrm{~cm}$, term baby, reflex and activity good, breathing well, crying and color is normal, $\mathrm{O}_{2}$ saturation $96 \%$ on room air, left foot skin damage (Figure 1), Scalp is normal, jaundice, edema cyanosis absent. On auscultation S1 S2 audible without any audible murmur. Movement of all limbs is normal except Left foot (Figure 1) where skin is deficient and covered by thin red membrane and restricted movement. Other system revealed normal.

Figure 2 shows after the age of six weeks, ongoing healing with secondary intention, but at the age of 16 to 18 weeks wound healed with a small crust (Figure 3 ) and finally at the age of 5 month showing the complete secondary healing of

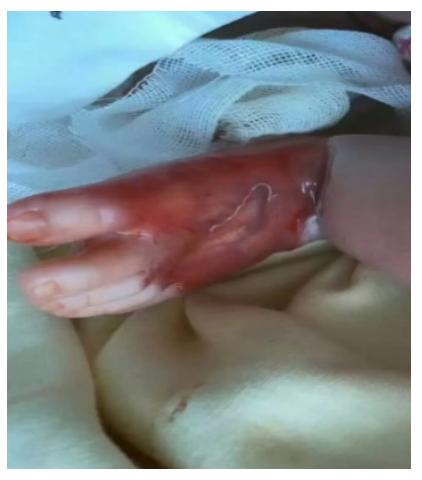

Figure 1. The newborn presented with the skin defect of the left foot on day one.

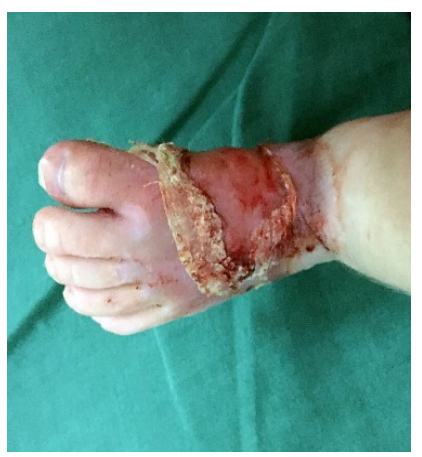

Figure 2. Six week postnatally, showed ongoing healing by secondary intention. 
the aplasia cutis Congenita defect (Figure 4). Figure 5 shows the images of "Skin Biopsy": From ulcerated lesion.

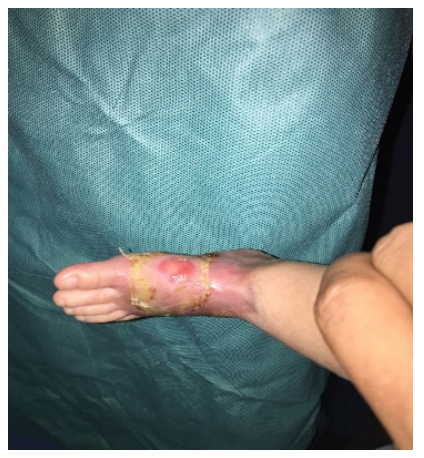

Figure 3. At the age of $16-18$ weeks the wound healed with a small crust remaining.

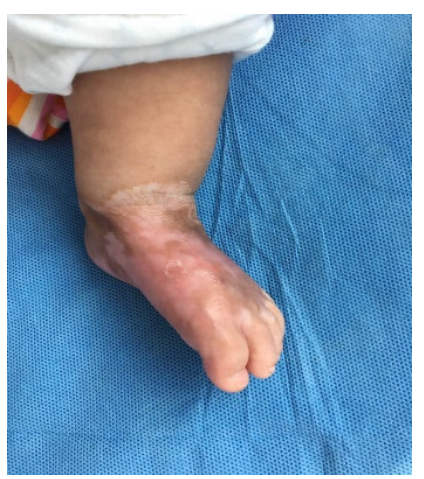

Figure 4. At the $5^{\text {th }}$ months, showing the complete secondary healing of the aplasia cutis congenita defect.

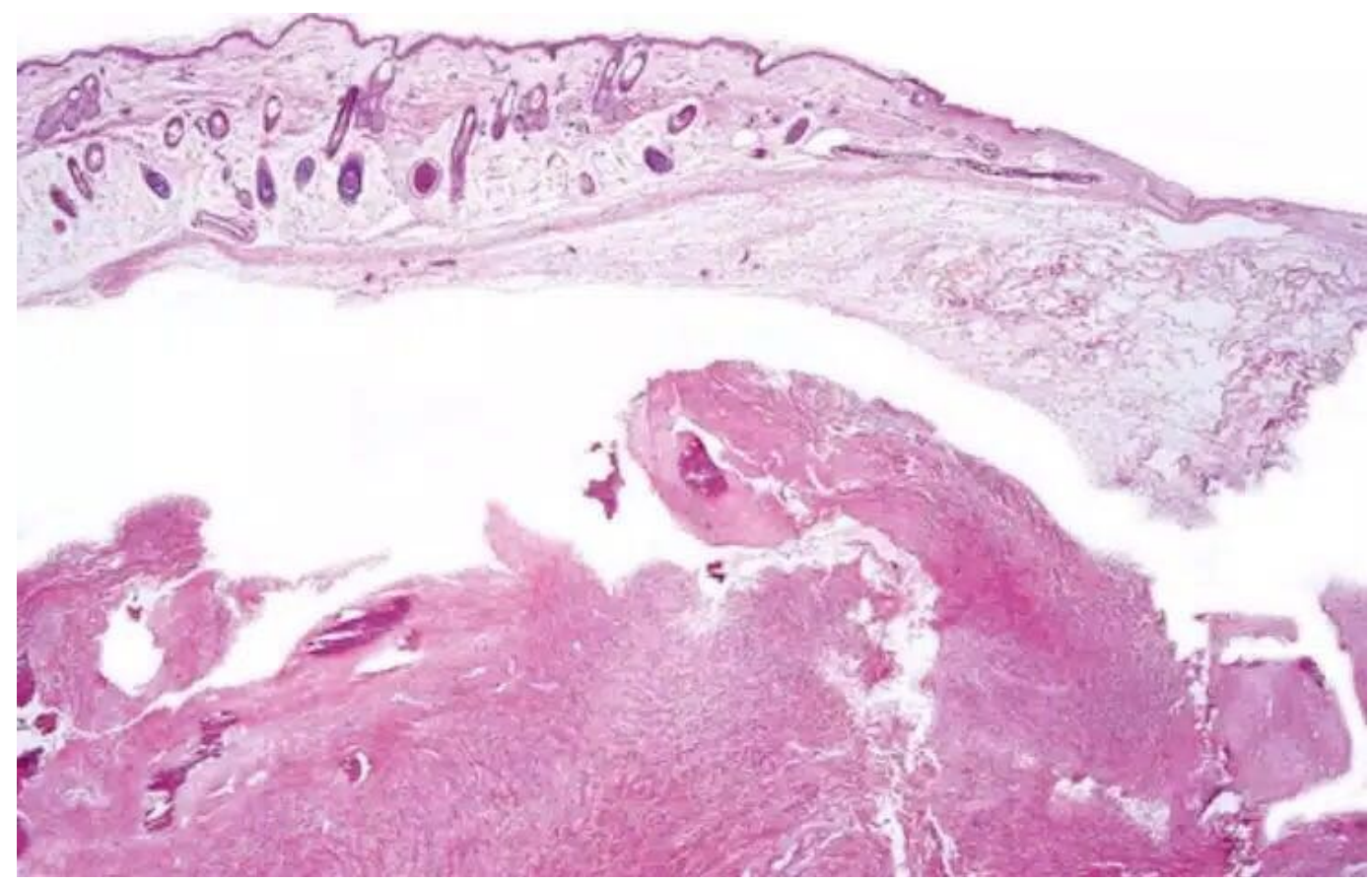

Figure 5. Images of "skin biopsy": From ulcerated lesion. 
Table 2. Blood investigation parameters of the patient.

\begin{tabular}{ccc}
\hline parameters & Normal ranges & results \\
\hline HBG & $15.0-24.0 \mathrm{~g} / \mathrm{dl}$ & $19.8 \mathrm{~g} / \mathrm{dl}$ \\
WBC & $9-38(\times 103 / \mu \mathrm{L})$ & $11,000 / \mathrm{cumm}$ \\
PLT & $125-350 \times 109 / \mathrm{L}$ & $180,000 / \mathrm{cumm}$ \\
RBS & $80-180 \mathrm{mg} / \mathrm{dl}$ & $85.9 \mathrm{mg} / \mathrm{dl}$ \\
USG of brain & normal & normal \\
X-ray of lower limb & normal & normal \\
CRP & negative & negative \\
Blood C/S & normal & normal \\
\hline
\end{tabular}

Initial diagnosis; Macrosomia with Congenital skin defect.

\subsection{Investigation}

Table 2 showed blood investigation parameters of the patient in the given number.

\section{Discussion}

ACC occurs as a solitary defect; it can happen alone or in the presence of syndromic congenital anomalies. The involvement of the scalp area may lead to the understanding of the etiology. Upon our review to the literature available, Cases were often characterized by an entire absence of skin. Histologically, we found that most of the lacking tissues belonged to epithelial ectoderm. The condition could be associated with chromosomal defects [12]. Some researches show the association with gestational conditions such as an intrauterine vascular ischemia, amniotic adherences, and viral infections [13] [14]. A rise of alpha-fetoprotein levels and a distinct amniotic fluid acetylcholinesterase band were found in recent article as markers for ACC [15]. Also, a number of drugs have been linked to ACC. For example, the use of cocaine during pregnancy can lead to vasoconstriction of the placenta or disruption of the fetus vascularity, causing the cranial defects and anomalies of the central nervous system (CNS) [16]. Methimazole, a drug used for the treatment of hyperthyroidism, may show some skin affection. Benzodiazepines use is also linked with ACC as described by Martínez-Lage et al. [7]. Surgical treatment requires careful preoperative planning [17]. Minimal superficial lesions are treated conservatively to heal gradually by epithelialization and result with a hypertrophic or atrophic scar. Tissue expander insertion may be necessary in extensive lesions reaching the scalp, whereas the one deep enough to reach the brain, bone, and meningeal transplants may be indicated [8] [18] [19] [20]. Deep defects overlying the sagittal sinus are indicators for urgent surgical intervention to prevent potentially lethal infections or hemorrhage [7] [21]. Grafting [22] and temporary use of biological dressings [23] and silver sulfadiazine dressings while waiting for the processes of skin and bony in growth [3] have been published with variable degree of success. A broad approach of therapeutic approaches are still being used for ACC. Due to the characteristics of 
this study we were still unable to determine that which treatment is best for ACC. On the other hand surgical management is generally preferred, especially for the large lesions, as it can prevent fatal complications and the cosmetic results are better.

\section{Conclusion}

We believe that ACC is a disease that carries the risk of potentially fatal complications, but that these can be prevented with an appropriate treatment. Aplasia Cutis Congenita is a rare congenital disorder characterized by absence of skin, most frequently overlying the scalp. ACC can be associated with many anomalies. We report a case of a newborn with isolated leg and foot ACC, which was treated conservatively. Although neither of the parents had ACC.

\section{Acknowledgements}

This work was supported by a grant from the National Natural Science Foundation of China (No. 810705390).

\section{Disclosure of Conflict of Interest}

The authors declare that they have no conflict of interest regarding the publication of this article.

\section{References}

[1] Bajpai, M. and Pal, K. (2003) Aplasia Cutis Cerebri with Partial Acrania-Total Reconstruction in a Severe Case and Review of the Literature. Journal of Pediatric Surgery, 38, 1-3. https://doi.org/10.1053/jpsu.2003.50064

[2] O’Neill, J., Carter, M. and Warr, R. (2010) Aplasia Cutis Congenita. A Case of Scalp Defect Repair Using Two Opposing Bipedicled Local Flaps. Journal of Plastic, Reconstructive \& Aesthetic Surgery, 63, e242-e244.

https://doi.org/10.1016/j.bjps.2009.06.005

[3] Blunt, K., et al. (1992) Aplasia Cutis Congenita: A Clinical Review and Associated Defects. Neonatal Network: NN, 11, 17-27.

[4] Mazza, J.M., et al. (2015) Aplasia Cutis Congenita in a Setting of Fetus Papyraceus Associated with Small Fetal Abdominal Circumference and High Alpha-Fetoprotein and Amniotic Acetylcholinesterase. Pediatric Dermatology, 32, 138-140.

[5] Frieden, I.J. (1986) Aplasia Cutis Congenita: A Clinical Review and proposal for Classification. Journal of the American Academy of Dermatology, 14, 646-660. https://doi.org/10.1016/S0190-9622(86)70082-0

[6] Lassman, L. and Sims, D. (1975) Congenital Midline Scalp and Skull Defect. Archives of Disease in Childhood, 50, 958-960. https://doi.org/10.1136/adc.50.12.958

[7] Kruk-Jeromin, J., Janik, J. and Rykała, J. (1998) Aplasia Cutis Congenita of the Scalp. Dermatologic Surgery, 24, 549-553. https://doi.org/10.1111/j.1524-4725.1998.tb04205.x

[8] Argenta, L.C. and Dingmanm R.O. (1986) Total Reconstruction of Aplasia Cutis Congenita Involving Scalp, Skull, and Dura. Plastic and Reconstructive Surgery, 77, 650-653. https://doi.org/10.1097/00006534-198604000-00026

[9] Herbst, A.L. and Selenkowm H.A. (1965) Hyperthyroidism during Pregnancy. The 
New England Journal of Medicine, 273, 627-633. https://doi.org/10.1056/NEJM196509162731203

[10] Baid, S.K. and Merkem D.P. (2007) Aplasia Cutis Congenita Following in Utero Methimazole Exposure. Journal of Pediatric Endocrinology and Metabolism, 20, 585-586. https://doi.org/10.1515/JPEM.2007.20.5.585

[11] Chitnis, M., Carachi, R. and Galea, P. (1996) Familial Aplasia Cutis Congenita. European Journal of Pediatric Surgery, 6, 100-101. https://doi.org/10.1055/s-2008-1066481

[12] Honore, L.H., Dill, F.J. and Poland, B.J. (1976) Placental Morphology in Spontaneous Human Abortuses with Normal and Abnormal Karyotypes. Teratology, 14, 151-166. https://doi.org/10.1002/tera.1420140206

[13] Mannino, F.L., Jones, K.L. and Benirschke, K. (1977) Congenital Skin Defects and Fetus Papyraceus. The Journal of Pediatrics, 91, 559-564. https://doi.org/10.1016/S0022-3476(77)80502-7

[14] Evers, M.E., Steijlen, P.M. and Hamel, B.C. (1995) Aplasia Cutis Congenita and Associated Disorders: An Update. Clinical Genetics, 47, 295-301. https://doi.org/10.1111/j.1399-0004.1995.tb03968.x

[15] Dror, Y., et al. (1994) Aplasia Cutis Congenita, Elevated Alpha-Fetoprotein, and a Distinct Amniotic Fluid Acetylcholinesterase Electrophoretic Band. American Journal of Perinatology, 11, 149-152. https://doi.org/10.1055/s-2007-994576

[16] Whitley, C.B. and Gorlin, R.J. (1991) Adams-Oliver Syndrome Revisited. American Journal of Medical Genetics, 40, 319-326. https://doi.org/10.1002/ajmg.1320400315

[17] Östör, A.G. (1993) Natural History of Cervical Intraepithelial Neoplasia: A Critical Review. International Journal of Gynecological Pathology, 12, 186. https://doi.org/10.1097/00004347-199304000-00018

[18] Attalla, M.F. and El-Sayed, A.M. (1992) Scalp Aplasia Cutis Congenita: Closure by the L-Shaped Flap. Child s Nervous System, 8, 287-288. https://doi.org/10.1007/BF00300799

[19] Marble, M., et al. (2017) Missense Variant in UBA2 Associated with Aplasia Cutis Congenita, Duane Anomaly, Hip Dysplasia and Other Anomalies: A Possible New Disorder Involving the SUMOylation Pathway. American Journal of Medical Genetics Part $A, 173,758-761$.

[20] Dyall-Smith, D., Ramsden, A. and Laurie, S. (1994) Adams-Oliver Syndrome: Aplasia Cutis Congenita, Terminal Transverse Limb Defects And Cutis Marmorata Telangiectatica Congenita. Australasian Journal of Dermatology, 35, 19-22. https://doi.org/10.1111/j.1440-0960.1994.tb01794.x

[21] Peer, L.A. and van Duyn, J. (1948) Congenital Defect of the Scalp: Report of a Case with Fatal Termination. Plastic and Reconstructive Surgery, 3, 722-726. https://doi.org/10.1097/00006534-194811000-00010

[22] Bailie, M.F.B. (1983) Aplasia Cutis Congenita of Neck and Shoulder Requiring a Skin Graft: A Case Report. British Journal of Plastic Surgery, 36, 72-74. https://doi.org/10.1016/0007-1226(83)90016-4

[23] Lambert, J., Govaert, P. and Naeyaert, J. (1997) What Syndrome Is This? Pediatric Dermatology, 14, 330-332. https://doi.org/10.1111/j.1525-1470.1997.tb00971.x 
Submit or recommend next manuscript to SCIRP and we will provide best service for you:

Accepting pre-submission inquiries through Email, Facebook, LinkedIn, Twitter, etc. A wide selection of journals (inclusive of 9 subjects, more than 200 journals)

Providing 24-hour high-quality service

User-friendly online submission system

Fair and swift peer-review system

Efficient typesetting and proofreading procedure

Display of the result of downloads and visits, as well as the number of cited articles Maximum dissemination of your research work

Submit your manuscript at: http://papersubmission.scirp.org/

Or contact ojped@scirp.org 